\title{
PENGATURAN MONOPOLI KARTEL OLEH PELAKU USAHA DALAM PERSAINGAN USAHA GARAM : SUATU KAJIAN PUTUSAN KPPU NO. 10/KPPU-L/2005
}

\author{
Rizal Aji Pratama \\ Mahasiswa Program Studi Magister Hukum \\ Universitas Semarang
}

\begin{abstract}
ABSTRAK
Undang-Undang RI No. 5 Tahun 1999 Tentang Larangan Praktek Monopoli Dan Persaingan Usaha Tidak Sehat merupakan pedoman bagi pelaku usaha untuk menjalankan usahanya agar terciptanya persaingan usaha yang kondusif dan sehat. Dalam implementasinya, peraturan tersebut belum ditaati oleh seluruh pelaku usaha. Terbukti dengan adanya praktek kartel garam yang dilakukan di daerah Sumatera Utara, bahwa ada 7 (tujuh) pelaku usaha yang melakukan perjanjian kartel yakni PT Garam, PT Budiono, dan PT Garindo yang bertindak sebagai pemasok garam yang disebut dengan kelompok G3 dengan PT Graha Reksa, PT Sumatera Palm, UD Jangkar Waja dan UD Sumber Samudera yang disebut dengan kelompok G4. Praktek tersebut menyebabkan kerugian bagi konsumen serta persaingan usaha tidak sehat. Berdasar kondisi tersebut ada 2 (dua) permasalahan yang penulis ambil, yakni : Bagaimana pengaturan mengenai larangan praktek monopoli kartel dalam persaingan usaha garam dalam kajian putusan KPPU no. 10/KPPU-L/2005 dan Bagaimana pengaturan ideal mengenai praktek monopoli kartel dalam persaingan usaha garam dalam kajian putusan KPPU no. 10/KPPU-L/2005.

Metode pendekatan yang digunakan adalah metode penelitian yuridis normatif. Penelitian ini merupakan penelitian deskriptif analitis. Jenis data yang digunakan adalah data sekunder. Metode pengumpulan data meliputi studi kepustakaan dan studi dokumentasi yang kemudian dianalisis secara kualitatif.

Berdasarkan hasil penelitian, dapat diketahui bahwa pengaturan kartel diatur dalam Pasal 4 (larangan oligopoli), Pasal 5 - Pasal 6 (larangan penetapan harga), dan Pasal 11 (larangan kartel) Undang-Undang RI No. 5 Tahun 1999 Tentang Larangan Praktek Monopoli Dan Persaingan Usaha Tidak Sehat sedangkan untuk pengaturan idealnya perlu disempurakan dan/atau dirumuskan klausul pasal yang mengatur tentang perluasan definisi pelaku usaha, menerapkan penegakan hukum dengan asas ekstra teritorialitas, memperjelas kedudukan dan kewenangan KPPU, penyempurnaan penerapan liniciency program, perubahan sanksi administratif, pembenahan sistem merger.
\end{abstract}

Kata Kunci: Kartel, Persaingan Usaha Tidak Sehat, KPPU. 


\begin{abstract}
Republic of Indonesia Law No. 5 year 1999 concerning Prohibition of Monopolistic Practices and Unfair Business Competition is a guideline for business actors to carry out their business in order to create a conducive and healthy business competition. In its implementation, the regulation has not been adhered to by all business actors. It is proved by the practice salt cartels carried out in the area of North Sumatra. There are 7 (seven) business actors who entered into a cartel agreement namely PT Garam, PT Budiono, and PT Garindo which acted as salt suppliers called G3 groups with PT Graha Reksa, PT Sumatera Palm, UD Jangkar Waja and UD Sumber Samudera called G-4 groups. Such practices cause losses to consumers and unfair business competition. Based on these conditions there are 2 (two) problems that the author took to his consideration, namely: How is the regulation regarding the prohibition of cartel monopolistic practices in the salt business competition in the review of KPPU's decision no. 10/KPPU-L/2005 and How is the ideal arrangement regarding the cartel monopoly practices in the salt business competition in the review of KPPU's decision no. 10/KPPU-L/2005.

The approach method used was a normative juridical research method. This research is a descriptive analytical study. The type of data used was secondary data. Data collection methods include literature studies and documentation studies which were analyzed qualitatively.

Based on the results of the study, it can be seen that the cartel arrangement is regulated in Article 4 (prohibition of oligopoly), Article 5 Article 6 (prohibition of pricing), and Article 11 (cartel ban) of Republic of Indonesia Law No. 5 year 1999 concerning Prohibition of Monopolistic Practices and Unfair Business Competition while for ideal arrangements it is necessary to refine and/or formulate clauses in articles governing the expansion of the definition of business actors, implementing law enforcement with the principle of extra territoriality, clarifying the position and authority of KPPU, improving the implementation of the liniciency program, changes in administrative sanctions, revamping the merger system.
\end{abstract}

Keywords: Cartel, Unfair Business Competition, KPPU. 


\section{A. LATAR BELAKANG}

Hukum merupakan
ilmu sosial yang dalam
perkembangannya selalu
berubah
perkembangan jaman yang
semakin maju. Hukum tidak
dapat bersifat stagnan karena
posisi tersebut menjadikan
hukum tidak mampu
diterapkan dengan baik.
Hukum harus mampu
merespon perubahan setiap
perilaku mansia,
perkembangan sosial, sampai
pada perkembangan

(ekonomi) usaha atau bisnis.

Hukum yang mengatur tentang ekonomi ditujukan agar dalam aktivitas ekonomi dilakukan secara sehat (fair) dalam tolok ukur aturan yang berlaku, agar setiap aktivitas ekonomi tidak menimbulkan kerugian materiil maupun imateriil dari pelaku usaha maupun konsumen. Aktivitas perekonomian dalam perkembangannya semakin maju dan semakin kompleks, banyak sekali hal-hal atau terobosan aktivitas ekonomi yang dengan itu hukum harus mampu mengimbangi dan melindungi dengan mengaturnya. Seperti ketika pelaku usaha dalam bersaing dengan pelaku usaha lainnya harus dilakukan secara sehat (fair) sesuai aturan yang berlaku, tidak menggunakan cara yang melanggar hukum agar tidak menimbulkan dampak kerugian bagi konsumen dan pelaku usaha lainnya.

Secara umum dalam menjalankan aktivitas ekonomi, secara konstitusional negara Indonesia berdasar pada Pasal 33 Undang Undang Dasar Republik Indonesia (UUD NRI) 1945. Pasal 33 UUD NRI 1945 merupakan dasar perekonomian Indonesia. Pada pasal tersebut mengandung semangat dan cita -cita perekonomian dilaksanakan dengan paham kebersamaan dan asas kekeluargaan. Oleh karena itu dalam pembangunan hukum ekonomi Indonesia Pasal 33 Undang Undang Dasar 1945 sifatnya memaksa, sehingga dalam perundang-undangan bidang ekonomi dinyatakan bahwa mengutamakan kemakmuran masyarakat banyak, bukan kemakmuran individu-individu. Pesan konstitusional tersebut jelas bahwa yang dituju adalah suatu sistem ekonomi tertentu, yang bukan ekonomi kapitalistik (berdasar paham individualisme).

Kemudian dengan perkembangan perekonomian yang semakin kompleks, Negara Indonesia merespon aktivitas ekonomi seperti dalam hal persaingan usaha salah satunya dengan 
mengeluarkan Undang-

Undang RI No. 5 Tahun 1999

Tentang Larangan Praktek Monopoli Dan Persaingan Usaha Tidak Sehat. UndangUndang ini lahir dengan tujuan agar "usaha dapat tumbuh serta berkembang secara sehat dan benar, sehingga tercipta iklim persaingan usaha yang sehat, serta terhindarnya pemusatan kekuatan ekonomi pada perorangan atau kelompok tertentu." Undang-Undang RI No. 5 Tahun 1999 Tentang Larangan Praktek Monopoli Dan Persaingan Usaha Tidak Sehat secara garis besarnya mengatur mengenai perjanjian yang dilarang, kegiatan yang dilarang, posisi dominan, Komisi Pengawas Persaingan Usaha (KPPU), penegakan hukum, dan ketentuan lainlain.

Secara umum dalam melakukan usaha atau bisnis setiap pelaku usaha tentu tujuan utamanya adalah untuk mendapatkan keuntungan yang sebesar-besarnya. Pelaku usaha tentunya juga memiliki ambisi bahwa apa yang menjadi produk atau jasanya adalah benar-benar yang dibutuhkan dan yang paling dicari konsumen. Sehingga dengan itu pelaku usaha selalu ingin menguasai dalam hal pasar karena hal tersebut menunjukan

\footnotetext{
${ }^{1}$ Penjelasan Umum Undang-Undang RI No. 5 Tahun 1999 tentang Larangan Praktek Monopoli dan Persaingan Usaha.
}

eksistensi usaha dan dapat berdampak membawa keuntungan yang besar untuk pelaku usaha.

$$
\text { Praktek monopoli }
$$

tentunya merupakan suatu keuntungan yang dimiliki oleh pelaku usaha dalam menjalankan usahanya. Namun dalam kaidah-kaidah hukum yang berlaku, praktek monopoli dilarang karena merugikan konsumen dan pesaing usaha lainnya.

Lahirnya UndangUndang RI No. 5 Tahun 1999 Tentang Larangan Praktek Monopoli Dan Persaingan Usaha Tidak Sehat sebagai acuan dan pedoman dalam melakukan kegiatan usaha bagi pelaku-pelaku usaha untuk bersaing secara sehat (kondusif), namun demikan pada faktanya masih ada pelaku-pelaku usaha yang bersaing dengan pelaku usaha lainnya secara tidak sehat.

Seperti yang terjadi di daerah Sumatera Utara, terdapat praktek monopoli dan perjanjian penetapan harga jual atau yang disebut praktek kartel yang dilakukan oleh beberapa perusahaan garam. Hal tersebut merupakan praktek yang dilarang dalam Undang-Undang $\mathrm{RI}$ No. 5 Tahun 1999 Tentang Larangan Praktek Monopoli Dan Persaingan Usaha Tidak Sehat.

Diketahuinya praktek monopoli dan perjanjian penetapan harga jual atau 
yang disebut praktek kartel di Sumatera Utara berawal dari laporan dan pemeriksaan pendahuluan yang dilakukan oleh Komisi Pengawas Persaingan Usaha atau KPPU. Daerah Sumatera Utara merupakan provinsi yang tidak memiliki sentra produksi garam sehingga untuk memenuhi kebutuhan tersebut selalu mendatangkan garam bahan baku dari sentra produksi lain yaitu dari Madura.

\section{Komisi Pengawas}

Persaingan Usaha atau KPPU mengetahui ada persekongkolan secara lisan untuk penetapan harga dan praktek monopoli yang dilakukan oleh PT Garam, PT Budiono, dan PT Garindo atau sering disebut G3 dan PT Graha Reksa, PT Sumatra Palm, UD Jangkar Waja, UD Sumber Samudra atau sering disebut G4. Bahwa PT Garam, PT Budiono, dan PT Garindo atau sering disebut G3 menjual garam secara kontinu ke PT Graha Reksa, PT Sumatra Palm, UD Jangkar Waja, UD Sumber Samudra atau sering disebut G4. Bahwa posisi tersebut adalah PT Garam, PT Budiono, dan PT Garindo atau sering disebut G3 sebagai pemasok, sedangkan PT Graha Reksa, PT Sumatra Palm, UD Jangkar Waja, UD Sumber Samudra atau sering disebut G4 sebagai distributor. PT Garam, PT Budiono, dan PT Garindo atau sering disebut G3 menjual secara kontinu kepada PT Graha Reksa, PT Sumatra Palm, UD Jangkar Waja, UD Sumber Samudra atau sering disebut G4. Apabila ada perusahaan yang ingin membeli garam langusng dari PT Garam, PT Budiono, dan PT Garindo atau sering disebut G3 maka akan kesulitan dan harganyapun lebih mahal. $^{2}$

\section{Berdasarkan}

penjelesan tersebut terlihat PT Garam, PT Budiono, dan PT Garindo atau yang disebut G3 menguasai pasar sebagai pemasok garam, sedangkan PT Graha Reksa, PT Sumatra Palm, UD Jangkar Waja, UD Sumber Samudra sebagai distributor di provinsi Sumatera Utara.

\section{Berdasarkan}

kesenjangan antara cita-cita pembangunan ekonomi dan aturan dengan fakta yang terjadi dilapangan yang tidak berjalan seimbang serta terjadinya pelanggaranpelanggaran aktivitas ekonomi yang terjadi tentunya tidak lepas dari adanya kekurangan dari segi normatif, yakni peraturan perundangundangan yang mengatur mengenai persaingan usaha itu sendiri dengan itu Peneliti tertarik untuk membahas "PENGATURAN MONOPOLI KARTEL OLEH PELAKU USAHA DALAM

${ }^{2}$ Putusan KPPU NO. 10/KPPU-L/2005. HIm. 6 -7 


$\begin{array}{lr}\text { PERSAINGAN } & \text { USAHA } \\ \text { GARAM : SUATU KAJIAN } \\ \text { PUTUSAN } & \text { KPPU } \\ \text { 10/KPPU-L/2005." } & \end{array}$

\section{B. Pengaturan Mengenai Larangan Praktek Monopoli Kartel Dalam Persaingan Usaha Garam Dalam Kajian Putusan KPPU No. 10/KPPU-L/2005}

Persaingan usaha diatur dalam Undang-Undang RI No. 5 Tahun 1999 tentang Larangan Praktek Monopoli dan Persaingan Usaha Tidak Sehat. Undang-Undang RI No. 5 Tahun 1999 tentang Larangan Praktek Monopoli dan Persaingan Usaha Tidak Sehat dibentuk berdasarkan cita-cita yang terkandung dalam Undang-Undang Dasar NRI 1945, yakni sebagaimana yang tercantum dalam Pasal 33. Pasal tersebut menghendaki bahwa kesempatan yang sama bagi setiap warga negara untuk membuka dan melakukan usaha atau bisnisnya. Pasal 33 juga menghendaki bahwa setiap orang yang bersaing dalam usahanya harus secara sehat.

Dalam pelaksanaan peraturan tersebut dalam realisnya belum terlaksana dengan sempurna. $\mathrm{Hal}$ tersebut dibuktikan dengan diketahuinya pelaku usaha yang melakukan praktek monopoli dan perjanjian penetapan harga jual atau yang disebut praktek kartel yang dilakukan oleh beberapa perusahaan garam di daerah Sumatra Utara.

Komisi Pengawas

Persaingan Usaha atau KPPU mengetahui ada persekongkolan secara lisan untuk penetapan harga dan praktek monopoli yang dilakukan oleh PT Garam, PT Budiono, dan PT Garindo atau sering disebut G3 dan PT Graha Reksa, PT Sumatra Palm, UD Jangkar Waja, UD Sumber Samudra atau sering disebut G4. Bahwa PT Garam, PT Budiono, dan PT Garindo atau sering disebut G3 menjual garam secara kontinu ke PT Graha Reksa, PT Sumatra Palm, UD Jangkar Waja, UD Sumber Samudra atau sering disebut G4. Bahwa posisi tersebut adalah PT Garam, PT Budiono, dan PT Garindo atau sering disebut G3 sebagai pemasok, sedangkan PT Graha Reksa, PT Sumatra Palm, UD Jangkar Waja, UD Sumber Samudra atau sering disebut G4 sebagai distributor. PT Garam, PT Budiono, dan PT Garindo atau sering disebut G3 menjual secara kontinu kepada PT Graha Reksa, PT Sumatra Palm, UD Jangkar Waja, UD Sumber Samudra atau sering disebut G4. Apabila ada perusahaan yang ingin membeli garam langusng dari PT Garam, PT Budiono, dan PT Garindo atau sering disebut G3 maka akan 
kesulitan dan harganyapun lebih mahal. ${ }^{3}$

Kartel merupakan salah satu bentuk perjanjian yang dilarang dalam UndangUndang RI No. 5 Tahun 1999 tentang Larangan Praktek Monopoli dan Persaingan Usaha Tidak Sehat. Jenis perjanjian ini sering terjadi dalam praktek kegiatan usaha, yang ditentuakn oleh pelaku usaha di bidang tertentu, dengan maksud mencari keuntungan secara mudah atau bahkan menyingkirkan pesaing usaha tidak sehat. Jenis kartel yang paling umum terjadi dikalangan penjual adalah perjanjian penetapan harga dan perjanjian pembagian wilayah pasar atau pelanggan.

Dari apa yang dilakukan oleh G3 dan G4 melanggar beberapa peraturan yang diatur dalam Undang-Undang RI No. 5 Tahun 1999 tentang Larangan Praktek Monopoli dan Persaingan Usaha Tidak Sehat, yakni Pasal 4, Pasal 5, Pasal 6, dan Pasal 11.

Pasal-pasal tersebut diatas pada pokoknya mengatur larangan membuat perjanjian antara pelaku usaha dengan pelaku usaha lainnya untuk secara bersama-sama menetapkan harga atau mempengaruhi harga atas suatu barang

${ }^{3}$ Putusan KPPU NO. 10/KPPUL/2005. HIm. 6 -7 dan/atau jasa yang harus dibayar konsumen baik konsumen yang sama atau berbeda, melakukan penguasaan produksi barang dan/atau jasa yang dapat mengakibatkan praktek monopoli atau persaingan usaha tidak sehat.

Secara umum kartel akan merugikan perekonomian, karena para pelaku usaha anggota kartel akan setuju untuk melakukan kegiatan yang berdampak pada pengendalian harga, seperti pembatasan jumlah produksi yang akan menyebabkan inefisiensi alokasi. Kartel juga dapat menyebabkan inefisiensi dalam produksi ketika mereka melindungi pabrik yang tidak efisien, sehingga menaikkan biaya rata-rata produksi suatu barang atau jasa dalam suatu industri. $^{4}$

C.Pengaturan Ideal Mengenai Praktek Monopoli Kartel Dalam Persaingan Usaha Garam Dalam Kajian Putusan Kppu No. 10/KppuL/2005

Negara Indonesia sebagai negara hukum yang sistem hukumnya cenderung mengarah pada hukum tertulis (civil law) selalu mengedepankan aturan tertulis sebagai prioritas dalam penegakan hukumnya.

\footnotetext{
${ }^{4}$ Peraturan Komisi Pengawas Persaingan Usaha Nomor 4 Tahun 2010, HIm. 9.
} 
Meruntut dengan kondisi tersebut tentunya negara Indonesia telah banyak sekali mengeluarkan peraturan perundang-undangan, yang salah satunya adalah Undang-Undang $\mathrm{RI}$ No. 5 Tahun 1999 tentang Larangan Praktek Monopoli dan Persaingan Usaha Tidak Sehat.

Sebagai negara hukum dengan basis hukum tertulis, suatu peraturan yang diundangkan selalu dilihat dan tinjau secara berkelanjutan. Apakah aturan yang berlaku tersebut dalam aplikasinya mampu berjalan dengan baik atau tidak, serta masih relevan dengan perkembangan zaman atau tidak. Karena apabila peraturan tersebut tidak mampu memenuhi atau mengakomodir kebutuhan tersebut, maka memang sudah sepatutnya peraturan tersebut untuk di evaluasi dan kemudian kedepan untuk diperbaiki.

Dalam hal UndangUndang RI No. 5 Tahun 1999 tentang Larangan Praktek Monopoli dan Persaingan Usaha Tidak Sehat dalam pelaksanaan atau penegakan hukumnya harus ditinjau (dievaluasi) untuk mengukur efektivitasnya.

Dalam mengukur efektivitas Undang-Undang RI No. 5 Tahun 1999 tentang Larangan Praktek Monopoli dan Persaingan Usaha Tidak Sehat dalam penegakan hukumnya dapat menggunakan teori dari Lawrence Friedman dan Gustav Radbrcuh. Teori

Lawrence

Friedman menjelaskan bahwa efektivitas dalam penegakan hukum dapat diukur melalui struktur, substansi dan budaya hukum. Struktur hukum yaitu kerangka bentuk yang permanen dari sistem hukum yang menjaga proses tetap berada di dalam batasbatasnya.

Terkait dengan struktur disamping aparat hukum lainnya seperti kepolisian, jaksa, advokat, hakim, KPPU juga masuk dalam struktur penegakan hukum. KPPU merupakan lembaga yang secara khusus dibentuk untuk mengawasi dan menegakkan hukum terhadap terjadinya praktek-praktek monopoli dan persaingan usaha tidak sehat. Kewenagan yang dimiliki oleh KPPU menurut penulis mempunyai kewenangan yang tumpang tindih. Karena KPPU memiliki kewenangan mulai proses penyelidikan, penyidikan, penuntutan sekaligus peradilan. KPPU mempunyai kewenangan yang multifunctions. Dalam kondisi tersebut, menurut penulis kewenangan yang multifunctions tidak baik dalam hal penegakan hukum. Karena hal demikian sangat rawan penyalahgunaan wewenang (abuse of power).

Kelemahan 
selanjutnya dari sisi struktur Menurut Komisioner KPPU Anna Maria Tri Anggraini, KPPU selaku lembaga pengawas juga memiliki beberapa hambatan lain (dikutip dari materi "Seminar Amandemen UU 5/99 Apakah Satu-satunya Solusi Dalam Penegakan Hukum Persaingan Usaha yang Efektif?" pada 17 Maret 2011) yaitu: 5 Pembebanan multi tugas dan fungsi dengan pembatasan kewenangan, Ketidakjelasan status pegawai, Keterbatasan kuantitas pegawai: turn-over yang tinggi dan Keterbatasan anggaran operasional.

Selanjutnya tinjauan dari segi substansi, ada beberapa pasal yang harus direvisi demi terciptanya kondusifitas persaingan usaha dikemudian hari, yakni seperti pada Pasal 1 ayat 5 yang mengatur mengenai definisi pelaku usaha. Pada pokoknya definisi pelaku usaha dalam pasal tersebut adalah pelaku usaha yang didirikan serta berkedudukan atau sepanjang melakukan aktifitasnya di dalam wilayah Indonesia.

(online),

${ }^{5}$ Hukum Online, "sanksi KPPU",

http://www.hukumonline.com/klinik/detail /cl4657/kppu-berwenang-jatuhkansanksi-pidana perdata, diakses 1 agustus 2018)
Padahal pelaku usaha dalam perkembangannya tidak hanya dalam negeri saja, tetapi dapat juga dari luar tertiorial negara Indonesia.

Ketua KPPU Nawir Messi mengatakan perubahan ini harus dilakukan dan sangat penting apalagi definisi tersebut menggunakan asas ekstra teritorial. Menjadi penting sebab selama ini banyak peserta tender tidak hanya berasal dari Indonesia, tetapi juga ada yang berasal dari Amerika Serikat, Korea Selatan. Bahkan, hampir semua peserta tender tidak memiliki kantor perwakilan atau afiliasi apapun di Indonesia. ${ }^{6}$

Setelah itu, perlu disempurnakan dan diterapkannya leniency program dalam UndangUndang RI No. 5 Tahun 1999. "Leniency program adalah keistimewaan bagi pelaku usaha yang terindikasi melakukan kartel. Syaratnya, pelaku usaha tersebut bersedia membuka data dan informasi kepada KPPU mengenai kartel yang

\footnotetext{
${ }^{6}$ Hukum Online, "usulan perubahan anti praktik monopoli", (online),

http://www.hukumonline.com/berita/baca llt530dc5522d523/ini-beberapa-usulanperubahan-uu-anti-praktik-monopoli, diakses 7 Agustus 2018)
} 
dilakukan."7

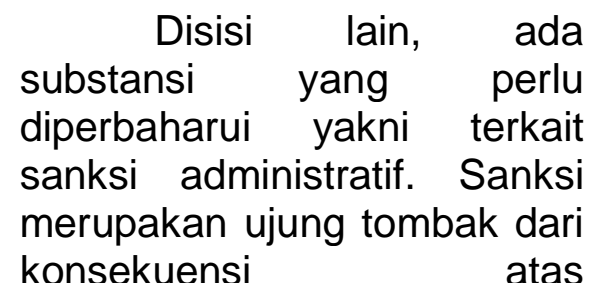
dilanggarnya sebuah aturan yang berlaku. Sanksi yang dapat diberikan oleh KPPU adalah sanksi denda sebagaimana yang tercantum dalam Pasal 47 tercantum pengenaan denda serendahrendahnya

Rp 1.000.000.000,00 (satu miliar rupiah) dan setinggi-tingginya Rp 25.000.000.000,00 (dua puluh lima miliar rupiah). Jika meninjau dari ketentuan tersebut, bagi pelaku-pelaku usaha yang melakukan kartel dengan keuntungan yang lebih besar daripada sanksi administratif tersebut maka bagi pelaku usaha akan tetap melakukan praktek kartel tersebut. Adanya batas (limit) atas sanksi administratif memiliki sisi kekurangan tersebut.

$$
\text { Adapun ketentuan }
$$

sanksi administratif lebih dapat memberikan efek jera bagi pelaku kartel adalah dengan menggunakan sistem presentase keuntungan kartel. Dalam sistem ini perlu juga diperhatikan kebijaksanaan pemangku jabatan yang (online),

${ }^{7}$ Hukum Online, "liniency program",

http://www.hukumonline.com/berita/baca /lt4d81f77e90173/bongkar-kartel-

dengan-leniency-program, diakses 9 agustus 2018) berwenang untuk mengenakan sanksi, karena apabila pengenaan sanksi ini terlalu tinggi maka dapat berdampak pada ruginya pelaku usaha yang bisa mengkibatkan gulung tikar. Dampak runtutan dari hal tersebut berimbas pada ketidakstabilan ekonomi dan para pekerja dari usaha tersebut bisa di PHK masal karena alasan efisiensi.

Selanjutnya dari substansi, harus dilakukan pengaturan dan pembenahan sistem meger. Sebagaimana dijelaskan dalam lampiran pedoman meger bahwa tindakan penggabungan, peleburan dan/atau pengambilalihan disadari atau tidak, akan mempengaruhi persaingan antar para pelaku usaha di dalam pasar bersangkutan dan membawa dampak kepada konsumen dan masyarakat. Merger dapat memberi dampak positif ketika dia berhasil mengalokasikan secara efisien dan efektif penggunaan sumber daya yang ada sehingga dapat menciptakan produk baru atau teknologi baru yang berguna untuk masyarakat.

Terlepas dari dampak positif merger jika berhasil dengan baik, dalam praktiknya selama ini semua penggabungan merger atau 
pengambilalihan perusahaan itu harus dilaporkan ke KPPU, tetapi persoalannya adalah laporan diserahkan kepada KPPU setelah merger atau akuisisi terjadi. Bagi pelaku usaha baiknya yang ingin melakukan merger atau akuisisi harus malapor ke KPPU. Jika diizinkan, maka merger baru boleh dilakukan. Cara ini lebih efektif untuk mencegah terjadinya kartel. ${ }^{8}$

Terakhir dari substansi yang perlu ditambahi adalah dari kelembagaan KPPU itu sendiri. Meninjau dari kewenangan KPPU yang multi-function yakni mulai dari pengawasan, penyelidikan, penyidikan, penuntutan, sampai pada pengadil atau pemutus akan sangat beresiko terjadinya penyalahgunaan wewenang (abuse of power). Ketidakjelasan

kedudukan KPPU sebagai lembaga negara dalam Undang-Undang RI No. 5 Tahun 1999 tentang Larangan Praktek Monopoli dan Persaingan Usaha Tidak Sehat, membawa implikasi terhadap status kelembagaan

\footnotetext{
${ }^{8}$ Hukum Online, (online), Revisi UU persaingan usaha",

http://www.hukumonline.com/berita/baca It575805e2373fo/uu-persaingan-usahadiubah--pahami-lima-fokus-revisi, diakses 11 agustus 2018)
}

KPPU yang belum terintegrasi dengan sistem kelembagaan dan kepegawaian nasional, meskipun pembiayaan operasional KPPU bersumber dari APBN. Sehingga sampai saat ini Anggota KPPU belum dianggap sebagai pejabat negara dan bahkan tidak pernah disumpah/ atau dilantik oleh Presiden/Mahkamah Agung meskipun di dalam UndangUndang RI No. 5 Tahun 1999 tentang Larangan Praktek Monopoli dan Persaingan Usaha Tidak Sehat dikatakan dalam Pasal 31 ayat (2) bahwa: Anggota Komisi diangkat dan diberhentikan oleh Presiden atas persetujuan Dewan Perwakilan Rakyat (DPR). ${ }^{9}$ Sub terakhir yang perlu ditinjau dari terkait budaya hukum dalam aktivitas ekonomi, peneliti mengkaji terbentuknya budaya adalah karena perilaku terus menerus atau diulang-ulang oleh manusia. Budaya hukum itu tidak lain dari keseluruhan faktor yang menentukan bagaimana sistem hukum memperoleh tempatnya yang logis dalam kerangka budaya milik masyarakat umum.

${ }^{9}$ Op cit, (online), http://www.dpr.go.id/doksileg/proses1/R J1-20170427-101602-9088.pdf 
Budaya hukum terkait ekonomi penting untuk diperbaiki dan selalu diawasi. Hal ini karena kegiatan ekonomi dalam prakteknya lebih mengarah pada pragmatisme. Pelaku-pelaku usaha secara ringkas tentunya ingin bagaimana caranya untuk mendapatkan keuntungan yang cepat dan sebanyak-banyaknya. Dalam kondisi inilah yang dapat mendorong pelaku usaha untuk melakukan perbuatan curang, dalam konteks ini melakukan praktek kartel. Dari sisi penegakan hukumnya, terkait dengan budaya hukum KPPU telah mampu bekerja dengan baik dan menindak lanjuti atas laporan serta pengawasan dalam persaingan usaha agar dilakukan secara sehat sebagaimana aturan hukum yang berlaku.

Kemudian tolok ukur kedua untuk efektif atau tidaknya atas penegakan hukum dan berlakunya Undang-Undang RI No. 5 Tahun 1999 Tentang Larangan Praktek Monopoli Dan Persaingan Usaha Tidak Sehat adalah teori dari Gustav Radbruch, yang menyebutkan bahwa hukum dan pengeakan hukum harus mencapai 3 (tiga) nilai tujuan yakni keadilan, kepastian hukum, dan kemanfaatan. Ketiga nilai yakni keadilan, kepastian hukum, dan kemanfaatan orientasinya adalah untuk menciptakan harmonisasi pelaksanaan dan penegakan hukum.

Mengenai nilai keadilan, keadilan secara filosofi hukum merupakan nilai paling mendasar dari tujuan hukum. Dalam sudut pandang ini dinyatakan bahwa tujuan hukum adalah untuk keadilan, jika tidak ada keadilan maka ia bukan hukum. Kemudian dalam kepastian hukum, merupakan perlindungan bagi semua subjek hukum dan dalam itu pula tercantum halhal atau tindakan apa saja yang boleh dilakukan dan tidak boleh dilakukan. terpelihara dan terjaminnya keteraturan (kepastian) dan ketertiban. Kepastian hukum merupakan kepastian undangundang atau peraturan, segala macam cara, metode dan lain sebagainya harus berdasarkan undang-undang atau peraturan. Terakhir mengenai kemanfaatan, bahwa dalam berlakunya sebuah peraturan perundangundangan dan penegakan hukumnya harus memberikan manfaat bagi masyarakat.

Sejak diberlakukannya 
Undang-Undang No. 5 Tahun 1999 tentang Larangan Praktek Monopoli dan Persaingan Usaha Tidak Sehat tatanan perekonomian Indonesia secara konstitusional telah memulai pergeseran dari ekonomi yang syarat dengan campur tangan negara menuju demokrasi ekonomi yang menghendaki adanya kesempatan yang sama bagi setiap warga negara untuk berpartisipasi di dalam proses produksi dan pemasaran barang dan/atau jasa sehingga mendorong ekonomi pasar yang wajar.

Dalam implementasi Undang-Undang No. 5 Tahun 1999 tentang Larangan Praktek Monopoli dan Persaingan Usaha Tidak Sehat secara umum telah memberi dampak baik dan menjawab nilai keadilan, kepastian, dan kemanfaatan. Namun harus diakui pula ada poin-poin yang harus dievaluasi agar ketiga nilai tersebut dapat diterapkann dengan baik untuk kedepan. Hal ini dikarenakan dalam perkembangan persaingan usaha yang begitu cepat dan kompleks, sehingga terkadang aturan hukum tertulis tidak mampu mengimbanginya. Dalam penegakan hukumnya konsekuensi dari peraturan tertulis disempurnakan melalui pendekatan kasuistik. Artinya, substansi Undang-Undang No. 5 Tahun 1999 tentang Larangan Praktek Monopoli dan Persaingan Usaha Tidak Sehat nantinya akan dilengkapi melalui putusanputusan KPPU. Dengan demikian, untuk dapat memahami konsep-konsep hukum persaingan usaha di Indonesia dan perkembangannya, pendekatan kasuistik juga dilakukan. Hal tersebut terkadang memiliki dampak positif yakni mencegah kekosongan aturan hukum, disisi lain juga memiliki dampak negatif yakni kurang terjaminnya kepastian hukum sehingga membuat pelakupelaku usaha berpikir bertindak apa yang tidak diatur dalam hukum adalah boleh.

\section{KESIMPULAN}

Dari uraian-urain pada bab sebelumnya, maka dapat disimpulkan bahwa :

1. Persaingan usaha diatur dalam Undang-Undang RI No. 5 Tahun 1999 tentang Larangan Praktek Monopoli dan Persaingan Usaha Tidak Sehat.

Dalam implementasinya peraturan 
tersebut belum dipatuhi secara utuh oleh pelaku usaha. Hal tersebut diketahui dari adanya praktek monopoli kartel garam yang terjadi di sumatera utara yakni ada 7 (tujuh) pelaku usaha yakni PT Garam, PT Budiono, dan PT Garindo yang bertindak sebagai pemasok garam utama yang disebut dan tergabung dalam kelompok G3 dan PT Graha Reksa, PT Sumatera Palm, UD Jangkar Waja dan UD Sumber Samudera yang disebut yang disebut dan tergabung dalam kelompok G-4 bertindak sebagai distribusi garam di Sumatera Utara. Dari praktek yang dilakukan oleh 7 (tujuh) pelaku usaha tersebut melanggar beberapa Pasal dalam Undang-Undang RI No. 5 Tahun 1999 tentang Larangan Praktek Monopoli dan Persaingan Usaha Tidak Sehat yakni Pasal 4 (larangan oligopoli), Pasal 5 - Pasal 6 (larangan penetapan harga), dan Pasal 11 (larangan kartel). Praktek tersebut tidak dapat dibenarkan karena tidak sesuai dan Tujuan pembentukan undang-undang ini adalah untuk menjaga kepentingan umum dan meningkatkan efisiensi ekonomi nasional, mewujudkan iklim usaha yang kondusif, mencegah praktek monopoli dan atau persaingan usaha tidak sehat yang ditimbulkan oleh pelaku usaha, terciptanya efektivitas dan efisiensi dalam kegiatan usaha.

2. Undang-Undang RI No. 5 Tahun 1999 tentang Larangan Praktek Monopoli dan Persaingan Usaha Tidak Sehat yang selama ini berjalan dibarengi dengan pesatnya perkembangan usaha tentunya ada evaluasievaluasi yang mengarahkan untu perbaikan guna mencapai aturan yang lebih ideal kembali. Diantaranya memperjelas kedudukan dan kewenangan KPPU, memperluas definisi pelaku usaha dengan menggunakan asas ekstra teritorial karena pelaku usaha tidak hanya dari dalam negeri saja, penyempurnaan leniency program untuk mengungkap praktek kartel lainnya, perubahan sistem sanksi adminitrasi denda dengan presentase keuntungan dari praktek kartel, pembenahan sistem meger untuk meminimalisir praktek kartel.

\section{D, SARAN}

Berdasarkan uraian-uraian pada bab sebelumnya terdapat beberapa kendala 
dalam implementasi dan pencegahan monopoli dan persaingan tidak sehat maka saran yang dapat disampaikan oleh peneliti adalah sebagai berikut :

1. Bagi pemerintah, bahwa pengaturan monopoli dan persaingan usaha tidak sehat perlu pembaharuan, agar tercapainya tujuan meningkatkan kesejahteraan rakyat dan menjaga kepentingan umum, mewujudkan iklim usaha yang kondusif, mencegah praktek monopoli dan atau persaingan usaha tidak sehat, terciptanya efektivitas dan efisiensi dalam kegiatan usaha. Adapun poinpoin penting yang harus dimasukan dan/atau disempurnakan dalam pembaharuan peraturan perundang-undangan tersebut yakni, perluasan definisi pelaku usaha, menerapkan penegakan hukum dengan asas ekstra teritorialitas, pembagian kewenangan KPPU, penyempurnaan penerapan liniciency program, perubahan sanksi administratif, pembenahan sistem merger.

2. Bagi pelaku usaha, dalam menjalankan usahanya wajib mematuhi kaidah-kaidah hukum yang berlaku khususnya peraturan perundang-undangan terkait anti monopoli dan persaingan usaha tidak sehat.

3. Bagi masyarakat, aktif dan kritis dalam memantau perkembangan kegiatan usaha dan/atau persaingan usaha yang dilakukan oleh pelaku usaha agar dapat mencegah persaingan usaha yang tidak sehat yang dapat merugikan masyarakat.

\section{DAFTAR PUSTAKA}

\section{BUKU}

Anthon Susanto, 2010, IImu Hukum Non Sistematik ;Fondasi Filsafat Pengembangan IImu Hukum Indonesia, Bandung : Genta Publishing.

Ashshofa, Burhan, 1996, Metode Penelitian Hukum Jakarta: Rineka Cipta.

Hanitijo Soemitro, Ronny, 1990, Metode Penelitian Hukum dan Jumitri, Yogyakarta: Ghalia Indonesia.

Lili Rasjididan I.B Wyasa Putra, 1993, Hukum Sebagai Suatu Sistem, Bandung : Mandar Maju.

M. Friedman, Lawrence, 2001, American law: An Introduction, Hukum Amerika:Sebuah Pengantar, 
Penerjemah:

Wishnu, Jakarta:

Tatanusa.

M. Friedman, Lawrence, 2009,

Sistem

Hukum ;Perspektif

IImu Sosial (The

Legal System ; A

Social Science

Perspective),

Bandung : Nusa Media.

Mukti Fajar ND dan Yulianto Achmad, 2013, Dualisme Penelitian Hukum Normatif \& Empiris. Yogyakarta : Pustaka Pelajar.

Pedoman Penulisan Usulan

Penelitian dan

Tesis, 2018,

Program Studi

Magister IImu

Hukum, Program

Pasca sarjana

Universitas

Semarang.

Soekanto dan Sri Mamudji,

Soerjono, 2004,

Penelitian Hukum

Normatif Jakarta:

Rajawali Pers.

Soekanto, Soerjono, 1984, Pengantar

Penelitian Hukum, Jakarta: Universitas Indonesia Press

Winarno, Surachmad, 2004, Dasar dan Teknik Research

Pengantar

Metodologi IImiah,

Bandung: $\quad \mathrm{CV}$

Tarsito.
Yosephus L. Sinuor, 2010, Etika Bisnis, Jakarta : Yayasan Pustaka Obor Indonesia, 2010.

$$
\text { PERUNDANG - UNDANGAN }
$$

Undang-Undang Dasar NRI 1945

Undang-Undang RI No. 5 Tahun 1999 Tentang

Larangan Praktek Monopoli Dan Persaingan Usaha Tidak Sehat

Peraturan Komisi Pengawas Persaingan Usaha Nomor 4 Tahun 2010.

INTERNET

DPR.go, Antimonopoli, Website http://www.dpr.go.id/ doksileg/proses1/RJ 1-20170427101602-9088.pdf.

Diakses tanggal 1 agustus 2018hukum online, sanksi KPPU, Website http://www.hukumon line.com/klinik/detail /cl4657/kppuberwenangjatuhkan-sanksipidana_perdata, diakses 1 agustus 2018

Hukum Online, usulan perubahan anti praktik monopoli, Website http://www.hukumon line.com/berita/baca 
/lt530dc5522d523/in

i-beberapa-usulan-

perubahan-uu-anti-

praktik-monopoli,

diakses 7 Agustus 2018

Hukum Online, Revisi UU

persaingan usaha,

Website

http://www.hukumon

line.com/berita/baca

/lt575805e2373f0/uu

-persaingan-usaha-

diubah--pahami-

lima-fokus-revisi,

diakses 11 agustus

2018 